\title{
CHALLENGES OF THE IMPLEMENTATION OF AIR QUALITY REGULATION AND STANDARDS IN MACEDONIA
}

\author{
Zoran Sapuric $^{1 *}$, Filip Ivanovski ${ }^{1}$, Dame Dimitrovski $^{2}$ \\ ${ }^{1}$ University American College, Skopje, Macedonia; \\ ${ }^{2}$ University St. Cyril and Methodius, Skopje, Macedonia; \\ *Corresponding author Zoran Sapuric, e-mail: sazoran@ hotmail.com; \\ f.ivanovski@t-home.mk; dame.dimitrovski@mf.edu.mk;
}

Received September, 2018; Accepted September, 2018; Published October, 2018;

DOI: https://doi.org/10.31407/ijees8428

UOI license: http://u-o-i.org/1.01/ijees/36107178

\begin{abstract}
One of the biggest environmental threats in Macedonia is related with pollution, especially in the capital city Skopje and in the bigger cities. There are many sources, which cause air pollution: transport, industry, energy, unsustainable constriction and special planning, overpopulation in the urban areas and also in some areas unfavorable geographic conditions. Combating with air pollution is a big challenge for central and local government authorities and for all involved stakeholders. Air pollution affects health and quality the citizen's life. European Union, as one of the world leaders in the field on the environment has been acting permanently for the improvement of the environment, including ambient air quality. The EU regulation stipulates high level of air quality standards. The main objectives of this regulation is to provide the conditions for reduction of air pollution which leads toward to better health protection and better quality of life. The EU ambient air quality legal regulation is very dynamic and it is based on the scientific research and consultation with all involved stake holders. Macedonia as state with candidate status for the full membership of EU has an obligation to transpose the EU regulation into the national legislation. This also applies to the air quality. In 2004 it was adopted the Law on ambient air quality which has amended several times. The Law is detailed in several sub law acts. This national regulation transposes the main principles of EU legislation, but the problem appears with its practical implementation. The aim of this paper is to analyze the ambient air quality regulation and standards in Macedonia and its practical implementation and to compare this with the EU regulation and to give some recommendations.
\end{abstract}

Key words: regulation, standards, ambient air, quality, European Union. 